\title{
Chinese Science: a Flexible Response to the West?
}

\author{
Peter C. Perdue
}

Received: 9 February 2007 / Accepted: 9 February 2007 /

Published online: 15 November 2007

(C) National Science Council, Taiwan 2007

Book: Benjamin A. Elman, A cultural history of modern science in China Cambridge, Mass.: Harvard University Press, 2006

Reviewer:

Peter C. Perdue

Massachusetts Institute of Technology

In this provocative synthesis, Ben Elman argues for the enduring significance of science, technology, and medicine in China from late imperial to modern times. Like other modern historians, he explicitly links abstract science with technologies for handling nature and the human body, and roots intellectual history in broader social trends. This is not a specialized history of science in China, but a world history of China with scientific characteristics. Anyone looking for a concise summary of the best recent scholarship on science in China should start here.

Drawing heavily on his longer monograph, In Their Own Terms: Science in China, 1550-1900, (Cambridge, Mass.: Harvard University Press, 2005), Elman surveys four major periods of scientific and technological development: the encounter with the Jesuits in the late sixteenth to seventeenth centuries, the lesser-known eighteenth century, the Protestant impact of the nineteenth century, and the period of selfstrengthening up through the aftermath of the Sino-Japanese war. He ranges over many fields of investigation, paying attention to astronomy, biology, botany, cartography, manufacturing, mathematics, medicine, and military technology.

Most Chinese and Western readers probably still believe that, with a few exceptions, Confucian literati of the imperial age ignored the investigation of nature, and that China failed to initiate a scientific revolution because of this neglect. Elman avoids the unanswerable question of why China did not have the world's first scientific revolution. Instead, he emphasizes active interaction by literati with the Westerners who brought modern science to China. They showed great curiosity

P. C. Perdue ( $\square)$

E51-291 History Faculty, Massachusetts Institute of Technology, 77 Massachusetts Avenue,

Cambridge, MA 02139-4307, USA

e-mail: pcperdue@mit.edu 
about new discoveries and inventions. They eagerly acquired and published new astronomical theories, and they collected mechanical clocks.

$\mathrm{He}$ also stresses that the Westerners who brought the scientific revolution to China, both the Jesuits and the nineteenth-century Protestant missionaries, deliberately put on blinders, filtering Western advances through religious screens. Jesuits, under orders from the Pope, concealed the prominence of the heliocentric model of the planetary system, instead promoting the compromise of Tycho Brahe, which still put the earth at the center, but placed the other planets orbiting the sun. Chinese interested in modern astronomy thus only received a partial view of the new science. Protestants likewise equivocated when they discussed Darwin, upholding a natural theology tradition which masked the destructive implications of natural selection. Western literati themselves, embedded in Christian theology, made strenuous efforts to accommodate disturbing advances in investigation of nature within traditional frames. It is no surprise that the Chinese did the same. What stands out from Elman's account is the flexibility and dynamism of the Chinese tradition of "investigation of things."

Joseph Needham, of course, made a powerful argument for the diversity and richness of the classical Chinese tradition of investigation of nature, but he mainly discussed the period before the Jesuits arrived. He aimed to fit Chinese achievements within a fixed model of scientific disciplines and to show that Chinese scholars anticipated discoveries of modern science. Needham's scheme of scientific disciplines is now outdated, and by repeatedly stressing Chinese anticipation of modern Western discovery, he pushed out of shape his other determined effort to see Chinese science on its own terms. For all his encylopedic knowledge, Needham's social analysis of the roots of Chinese science, unfortunately, was never nuanced. Elman greatly improves on Needham by describing global social and political contexts for important Chinese scientific developments. Good-bye to "bureaucratic feudalism!"

Elman also shows that, contrary to the argument of Derk Bodde, the classical Chinese language posed no obstacles to the introduction of modern mathematical terminology. Instead, the mathematical tradition absorbed many Western techniques.

Likewise, herbal manuals and medicinal texts could accept Western anatomy without putting great stress on it. Since Western surgical techniques had no obvious advantages over Chinese herbalism until the end of the nineteenth century, the Chinese medical tradition could assert its autonomous validity. When China's southward expansion exposed new settlers to virulent tropical diseases, physicians debated proper treatment for "heat factor disorders" that differed from classical descriptions. Without adopting a germ theory, they responded to the presence of new diseases. By the end of the nineteeth century, Xu Shou called for critical reexamination of the medical tradition and selective incorporation of Western techniques. Syncretism, not obscurantism, marked much of classical China's response to Western science and technology through the end of the nineteenth century.

Elman argues that the self-strengthening movement had notable successes, and that science and technology promoted at the arsenals and dockyards often surpassed that of Japan. Only the Japanese victory in 1895 made self-strengthening look like a failure. But Japan's victory came from superior organization, not from superior technology. Japan threw its entire nation into the war, while the commander of China's southern fleet, who had already engaged the French in the South, reserved 
his resources for southern defense. China's bigness, not its traditional civilization, was its greatest weakness.

Chapter 3, on manufacturing and trade, addresses indirectly the issue of the Industrial Revolution. Elman portrays vividly the advances of Chinese artisanal work in porcelain, glass making, and printing. He shows that Chinese eagerly took up manufacture of European clocks when the emperors indicated an interest in them, but the "Newtonian revolution" of mathematically based empirical investigation reached China very late. Elman recognizes that the great sophistication of Chinese manufacturing calls into question the "European-dominated story of the rise of modern techno-science" (p. 98), but he seems to agree with certain economic and intellectual historians who argue that the production of "useful and reliable knowledge" (URK) based on scientific investigation was the key to Europe's pioneering advances in coal and steam-powered industrialization. These scholars try to link the entire European intellectual tradition from Newton to the Enlightenment directly to the Industrial Revolution. Elman writes that "the steam engine linked Newtonian merchanics and engineers in a cycle of manufacturing and industrial advances that soon led to the the efficient use of natural deposits of fossil fuels and thus an unprecedented amount of new energy for practical work in factories, arsenals, and on ships." (p. 93) But he neglects to mention the important Chinese production of URK in the statecraft school of scholars, who wrote insightful essays about mining, agricultural yields, water conservancy, currency, and taxation: in short, the political economy of agrarian development. I think the case is yet to be proven that abstract Newtonian knowledge really had a serious direct impact on European industrialization, and in any case China had its own kind of URK if not in Newtonian form. Pomeranz's material explanation for the "Great Divergence" of the nineteenth century is more convincing than arguments for defects in Chinese intellectual abilities.

The catastrophe of the Sino-Japanese war, however, discredited nearly all of the achievements of the previous three centuries, leading to radical attacks on tradition and violent erasure of the past. These totalistic dismissals of imperial China's scientific and technological achievements erased much valuable historical knowledge and threw China into uncritical adulation of the West. Needham attacked Western historians for their biases, but neglected to note that Chinese themselves held even more fervent Orientalist views of their own past as stagnant and worthy of rejection.

Only now, as China reenters a global economy from a position of strength, having rejected radical revolution in favor of reform, has space opened up for new understanding of imperial China's distinctive path to modernity. The rich "blending of natural learning that occurred from 1600 to 1900 " (p. 226) needs serious attention from scholars and readers who want informed perspectives on China in the contemporary world. 